\title{
Systematic Risk Measurement and Management of Multinational Banks Based on GARCH-CoVaR
}

\author{
Jiaxi $\mathrm{Wu}^{1, \mathrm{a}}$, Jian $\mathrm{Min}^{2}$, b, * \\ ${ }^{1}$ Nanhu campus of Wuhan university of technology, Wuhan city, \\ Hubei province, the People's Republic of China \\ ${ }^{2}$ college of management of Wuhan university of technology, Wuhan city, \\ Hubei province, the People's Republic of China \\ a961171434@qq.com, b20431622@qq.com \\ *Jiaxi Wu
}

Keywords: Systemic risk, GARCH-CoVaR method, Prevention and control path

\begin{abstract}
Finance plays a key role in the economy. Financial risks are very sudden, infectious and harmful. How to effectively reduce and prevent the negative impact of systemic financial risks is an urgent problem. On the basis of summarizing the research results of systematic risk measurement at home and abroad, this paper sums up the definition of systematic risk of banks, measures and analyzes the systematic risk of 10 transnational banks in China based on GARCH Covar method, and finally puts forward some suggestions for preventing systematic risk.
\end{abstract}

\section{Introduction}

With the development of economy and the acceleration of globalization, the economic and financial relations of all countries are increasingly close, but at the same time, the transmission of financial risks is also strengthened. In the period of financial crisis, the linkage between financial institutions will be strengthened invisibly, which will lead to faster risk propagation, wider range and greater harm.

\section{GARCH-CoVaR method}

\subsection{CoVaR method}

Since brunnemeier and Adrian first proposed the concept and theory of CoVaR to measure the value at risk of a financial system when an institution is in crisis (when the loss is its VaR value), and used the linear quantile regression method to estimate CoVaR, which has attracted the attention of many scholars. On this basis, many foreign scholars try to use different methods to calculate CoVaR, which is used to measure the systematic risk contribution of an institution and the Risk Spillover Effect between different markets. Conditional value at risk refers to the VaR risk level of financial institution I when the loss of financial institution is at the level of var. Conditional VaR includes both unconditional $\mathrm{VaR}$ and spillover var. Therefore, the spillover risk value $\triangle \mathrm{CoVaR}$ is the difference between the conditional risk value and the unconditional risk value.

\subsection{Introduction to GARCH model}

GARCH model is called generalized arch model, which is an extension of arch model and developed by bollerslev (1986). After Engle (1982) proposed arch model to analyze the heteroscedasticity of time series, t. bollerslev (1986) proposed GARCH model. GARCH model is a regression model specially designed for the financial data volume. Except the same place as the general regression model, GARCH further modeled the variance of error. 


\section{An empirical analysis of financial risks of multinational banks}

This paper selects 10 multinational banks in China, all of which refer to the top 15 of China's top 100 banks in 2018 and relevant materials, and strictly controls the gap between these banks, applies GARCH Covar method to measure financial risk, and analyzes and elaborates the empirical results of these 10 banks.

\subsection{Data selection}

The 10 selected multinational manufacturing enterprises and their stock codes are as follows: Industrial and Commercial Bank of China (601398), China Everbright Bank (6001818), Huaxia Bank (600015), China Construction Bank (601939), Bank of Communications (601328), China Minsheng Bank (600016), Agricultural Bank of China (601288), Shanghai Pudong Development Bank (600000), Industrial Bank (601166) and Bank of China (601988). We select the daily closing price from July 1, 2014 to June 30, 2019 as the original data, taking a quarter or three months as a cycle, which can reduce the impact of short-term fluctuations. The data selection interval is based on the following two points: first, the data in this interval is relatively new, which can be more prepared to reflect the financial risk changes of these banks in recent five years to some extent. Secondly, the interval data is relatively complete, and all the data of enterprises can basically be obtained.

The daily rate of return is calculated by the closing price of individual shares. The rate of return is calculated in the form of price logarithm. To reduce the calculation error, the percentage rate of return is adopted, specifically RT $=100 \% * \ln \left(\mathrm{P}_{\mathrm{t}} / \mathrm{P}_{\mathrm{t}-1}\right)$. Eviews 9.0 software is used for data processing. The quarterly yield is the average daily yield of three months. The variance is calculated by the formula in the table.

\subsection{Data processing}

\subsection{1 normal test}

Using Eviews 9.0 software, we can simply analyze the statistical characteristics of the sample's return series. This paper selects the industrial and Commercial Bank of China's return series as a representative to explain.

First of all, the peak value of this yield series is 7.447871, which is greater than the peak value of the standard normal distribution, 3, which indicates that there is an obvious peak and thick tail phenomenon in the yield series studied; secondly, the skewness value of -1.907141 is not 0 , which indicates that the series does not obey the normal distribution, and the skewness value is negative, which is left; finally, the JB statistics of this yield series is significant, The $p$ value is close to 0 , less than 0.05 , so we can reject the hypothesis that the yield is normal distribution, and the distribution of the yield shows the characteristics of thick tail.

Therefore, this paper can use GARCH model to simulate the yield series.

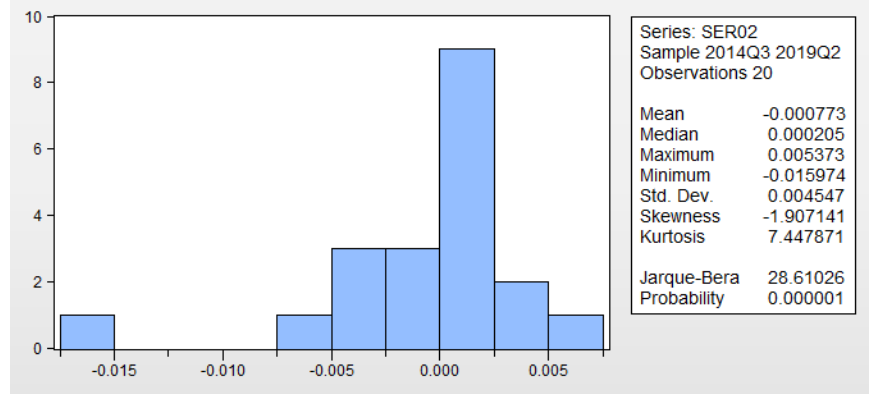

Chart 1. Statistical characteristic chart of industrial and Commercial Bank of China's yield series

Table 1. Yield statistical line description test

\begin{tabular}{|c|c|c|c|c|c|}
\hline Banks & Mean value & $\begin{array}{c}\text { standard } \\
\text { deviation }\end{array}$ & $\begin{array}{c}\text { Skewness } \\
\text { coefficient }\end{array}$ & Kurtosis & JB statistics \\
\hline $\begin{array}{c}\text { Industrial and Commercial Bank } \\
\text { of China }\end{array}$ & -0.000982 & 0.0056160 & -1.590210 & 6.211394 & 8.02344 \\
\hline Everbright Bank & -0.000391 & 0.004737 & 0.906457 & 4.152776 & 6.152776 \\
\hline
\end{tabular}




\begin{tabular}{|c|c|c|c|c|c|}
\hline Huaxia Bank & -0.002083 & 0.012203 & -1.417868 & 7.62781 & 10.6111 \\
\hline Bank for economic construction & -0.004966 & 0.21836 & 3.790808 & 9.27733 & 14.8069 \\
\hline Bank of Communications & -0.048589 & 0.024802 & -2.666853 & 11.08866 & 12.22906 \\
\hline Minsheng Bank & -0.000207 & 0.002433 & 0.649169 & 7.442762 & 6.377307 \\
\hline Agricultural Bank & -0.000664 & 0.001977 & 0.057692 & 9.742749 & 8.066243 \\
\hline Pudong Development Bank & -0.000364 & 0.002981 & 0.352945 & 8.507925 & 9.310100 \\
\hline Industrial Bank & -0.000773 & 0.004547 & -1.907141 & 7.447871 & 13.61026 \\
\hline Bank of China & -0.003957 & 0.002782 & 0.382963 & 10.152743 & 11.087073 \\
\hline
\end{tabular}

\subsubsection{Stability test}

For time series data, unit root test is generally carried out before analysis to judge the stability of variables. Only the series meeting the stability conditions are suitable for AR model analysis, otherwise the analysis of non-stationary series will produce pseudo regression phenomenon, which will affect the analysis effect. The unit root test is usually used as the test method, which includes DF and ADF. In this paper, ADF is used to test the stability of the sequence. Take industrial and Commercial Bank of China as an example to test the stability of its yield series. The ADF unit root test results are shown in the table.

\begin{tabular}{lccc}
\hline \hline & t-Statistic & Prob. $^{*}$ \\
\hline \hline Augmented Dickey-Fuller test statistic & -4.385543 & 0.0032 \\
\hline Test critical values: & $1 \%$ level & -3.831511 & \\
& $5 \%$ level & -3.029970 & \\
& $10 \%$ level & -2.655194 & \\
\hline \hline
\end{tabular}

Chart 2.ADF test results of industrial and Commercial Bank of China

Table 2.ADF unit root test results

\begin{tabular}{|c|c|c|c|c|c|}
\hline Banks & ADF & P value & banks & ADF & P value \\
\hline $\begin{array}{c}\text { Industrial and } \\
\text { Commercial Bank of } \\
\text { China }\end{array}$ & -4.883262 & 0.0032 & Minsheng Bank & -6.339173 & 0.0103 \\
\hline Everbright Bank & -8.275792 & 0.0013 & Agricultural Bank & -4.511654 & 0.0057 \\
\hline Huaxia Bank & -3.984527 & 0.0089 & $\begin{array}{c}\text { Pudong Development } \\
\text { Bank }\end{array}$ & -3.842239 & 0.0161 \\
\hline $\begin{array}{c}\text { Bank for economic } \\
\text { construction }\end{array}$ & -7.74133 & 0.0000 & Industrial Bank & -4.385543 & 0.0002 \\
\hline $\begin{array}{c}\text { Bank of } \\
\text { Communications }\end{array}$ & -3.531560 & 0.0174 & Bank of China & -5.678470 & 0.0040 \\
\hline
\end{tabular}

\subsubsection{Correlation test}

For the time series of return rate, the current level may be affected by the previous level, i.e. there can be autocorrelation, so this part carries out the corresponding test and analysis of autocorrelation. The autocorrelation and partial autocorrelation of industrial and Commercial Bank of China's rate of return series lag, and the test results of the first 12 steps are given, as shown in the figure. At the same time, autocorrelation test is carried out for all samples, and the autocorrelation graph and partial autocorrelation graph do not have more than 5\% significant correlation lines. In conclusion, it can be considered that the sequence does not have autocorrelation. 


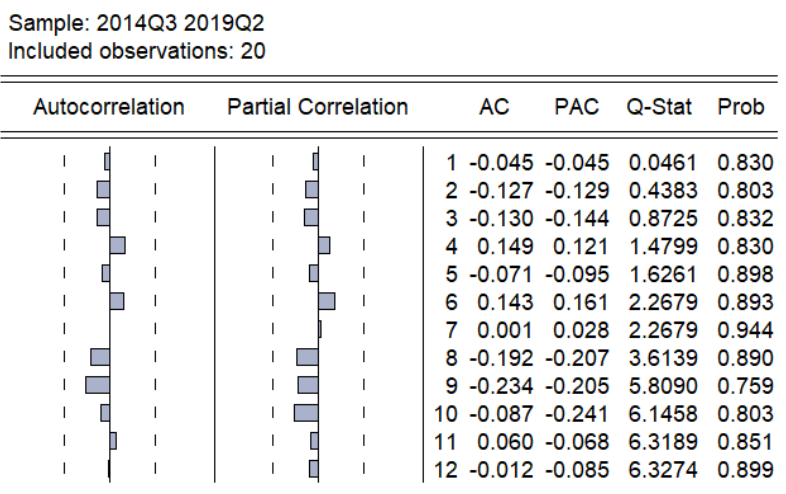

Chart 3. Industrial and Commercial Bank of China autocorrelation test results

\subsection{Measurement results}

\subsection{1 calculation of VaR}

Value at risk (VaR) is a common method to measure the risk level of financial institutions, which ignores the relationship and influence between financial institutions. Due to the close relationship between enterprises in the financial system, the risk will spread rapidly among banks during the crisis, and the systemic risk will increase correspondingly. However, VAR cannot capture the Risk Spillover Effect among financial institutions.

As can be seen from the table below, under the different tail distribution assumptions and analysis frameworks under different probability levels, the quarterly average var loss value of Bank of communications, Minsheng Bank and industrial and Commercial Bank of China is small, showing good risk resistance and robustness; while the quarterly average VaR value of Everbright Bank and bank of China is relatively large under the normal distribution.

Table 3. VaR of Chinese banks under 5\% normal distribution

\begin{tabular}{|c|c|c|c|c|c|}
\hline Banks & average value & Median & banks & $\begin{array}{c}\text { average } \\
\text { value }\end{array}$ & Median \\
\hline $\begin{array}{c}\text { Industrial and } \\
\text { Commercial Bank of } \\
\text { China }\end{array}$ & -0.0028 & -0.0030 & Minsheng Bank & -0.0027 & -0.0022 \\
\hline Everbright Bank & -0.0048 & -0.0051 & Agricultural Bank & -0.0034 & -0.0036 \\
\hline Huaxia Bank & -0.0034 & -0.0024 & $\begin{array}{c}\text { Pudong } \\
\text { Development Bank }\end{array}$ & -0.0037 & -0.0039 \\
\hline $\begin{array}{c}\text { Bank for economic } \\
\text { construction }\end{array}$ & -0.0037 & -0.0033 & Industrial Bank & -0.0033 & -0.0031 \\
\hline $\begin{array}{c}\text { Bank of } \\
\text { Communications }\end{array}$ & -0.0024 & -0.0013 & Bank of China & -0.0044 & -0.0048 \\
\hline
\end{tabular}

\subsubsection{Calculation of CoVaR}

Compared with VaR, Covar can well capture the negative externality effect of risk between financial institutions, and quantify various risk situations such as financial institutions being too big to fail, or highly related, or liquidity crisis caused by holding cross positions with each other into a potential loss value, so that regulators can intuitively grasp the risk situation. Covar measures the impact of Risk Spillover on the whole industry system when a financial institution has the greatest possible loss risk.

As can be seen from the table, compared with VaR value, the gap between cross-sectional samples of sample enterprises in Covar value is widened, mainly because Covar value includes the unconditional risk of the whole financial industry system. The results show that under the assumption of normal distribution of 5\%, SPDB, Bank of China and Agricultural Bank of China have the most significant contribution to the risk of the whole system. 
Table 4. CoVaR of Chinese banks under 5\% normal distribution

\begin{tabular}{|c|c|c|c|c|c|}
\hline Banks & $\begin{array}{c}\text { average } \\
\text { value }\end{array}$ & Median & banks & $\begin{array}{c}\text { average } \\
\text { value }\end{array}$ & Median \\
\hline $\begin{array}{c}\text { Industrial and } \\
\text { Commercial Bank of } \\
\text { China }\end{array}$ & -0.0039 & -0.0041 & Minsheng Bank & -0.0044 & -0.0040 \\
\hline Everbright Bank & -0.0045 & -0.0046 & Agricultural Bank & -0.0051 & -0.0052 \\
\hline Huaxia Bank & -0.0030 & -0.0026 & $\begin{array}{c}\text { Pudong } \\
\text { Development Bank }\end{array}$ & -0.0072 & -0.0074 \\
\hline $\begin{array}{c}\text { Bank for economic } \\
\text { construction }\end{array}$ & -0.0031 & -0.0030 & Industrial Bank & -0.0044 & -0.0043 \\
\hline $\begin{array}{c}\text { Bank of } \\
\text { Communications }\end{array}$ & -0.0036 & -0.0029 & Bank of China & -0.0052 & -0.0055 \\
\hline
\end{tabular}

\section{Prevention and control paths of systematic risk}

After using GARCH Covar method to study the systemic risk of 10 transnational banks in China, the paper puts forward the prevention and control path from three aspects: establishing scientific and reasonable early warning system, strengthening external supervision and strengthening international cooperation.

\subsection{Establish a scientific and reasonable early warning system}

Whether a country's financial environment is stable or not depends on a sound risk early warning system, which can facilitate real-time observation of the dynamics of financial institutions. By building a scientific and reasonable early warning mechanism, potential problem banks can be found in time, and appropriate measures can be taken for supervision, so as to effectively control the spread of risks before they occur. In addition, a scientific and reasonable financial risk early warning mechanism can monitor the operation of the financial system in real time and grasp the macroeconomic situation and international financial trends in time.

\subsection{Strengthen external supervision}

First of all, we should strictly monitor all kinds of security indicators, not only to measure the net assets, capital adequacy ratio, but also to consider the complexity and other factors. Secondly, we should establish a set of perfect system of pre-warning, in-process response and post-processing, quickly find out the problems at the first time when the risk occurs, and propose corresponding solutions to specific problems, so as to effectively curb the development and spread of risk before the risk spreads.

\subsection{Strengthening international cooperation}

China's banks are facing increasing input financial risks. To effectively prevent and properly handle these risks, we must strengthen international cooperation. On the one hand, it helps to understand the latest situation of the international market, adjust the direction and strategy of supervision; on the other hand, it can learn the advanced foreign supervision prevention and systematic risk measurement means, and improve the systematic risk supervision mechanism of China's banking industry. Combined with the actual situation of our country, this paper discusses the methods of measuring the systemic risk of our country's banking industry and strengthens the supervision measures.

\section{Conclusion}

Because of the complexity and uncontrollability of the environment, the influencing factors of the financial risk of Chinese multinational banks are increasingly complex and difficult to measure. Through the appropriate financial risk measurement model to measure and compare the data, the paper finally gives the prevention and control and management of financial risk of multinational companies from three aspects: establishing a scientific and reasonable early warning system, 
strengthening external supervision, and strengthening international cooperation.

\section{Acknowledgment}

This research was financially supported by "the Fundamental Research Funds for the Central Universities" (2018VI002).

\section{References}

[1] Sun Jinlei. Research on systematic risk measurement of Chinese Commercial Banks Based on GARCH Covar method [D]. Hunan University, pp.21-37,2014

[2] Zheng Zhexi. Research on systematic risk management and control of Ping An insurance group of China based on GARCH Covar model [D]. Shanghai Normal University, pp.25-41, 2018

[3] Liu Xiangli, Gu Shuting. Research on the Risk Spillover Effect of real estate on financial system based on ar-garch-covar method [J]. System engineering theory and practice, pp.1-10, 2014,34 (S1): 106-111

[4] Gao Guohua, pan Yingli. Systematic risk measurement of banks: an analysis based on dynamic Covar method [J]. Journal of Shanghai Jiaotong University, pp.1-7, 2011,45 (12): 1753-1759

[5] Zhang Lu, Zhang Xiting. Systematic risk measurement of China's Listed Banks Based on Covar model [J]. Statistics and management, pp.1-5, 2017 (11): 66-70

[6] Zhang Liying. Measurement of China's systematic financial risk and analysis of its influencing factors [D]. Capital University of economics and trade, pp.21-50, 2018

[7] Sun fan. Research on systematic risk of China's Listed Banks Based on Covar method [D]. Suzhou University, pp.17-51, 2016

[8] Tao Ling, Zhu Ying. Monitoring and measurement of systemic financial risk -- Based on the study of China's financial system [J]. Financial research, pp.3-17, 2016 (06): 18-36 